\title{
Proton Radiation
}

National Cancer Institute

\section{Source}

National Cancer Institute. Proton Radiation. NCI Thesaurus. Code C40431.

Radiation of protons during radioactive decay. 